\title{
Misrecognized Violence against Women and Perpetrated by Women. Seeking Remedies
}

Joanna Dutka (Adam Mickiewicz University)

\section{Introduction}

This paper deals mainly with physical violence and its recognition. Other forms of violence will be mentioned only in relation to physical violence. Sexual abuse is classified here as a form of physical violence affecting the physical body. This is based on the assumption that there may be differences in the patterns of other forms of violence and mechanisms they trigger.

It is important to know how violence affects people's lives, who falls victim to violence and who uses it, and what the circumstances are for such happenings. Therefore, in order to understand the way violence contributes to the construction of the social order, we have to realize who is responsible for making decisions about the legitimate use of violence and in what circumstances these decisions are taken. It is essential to understand how and why violence is being excused and/or erased, and who the victims are. In spite of the fact that violence and the discourse surrounding it affect women's social experience, women are still under-represented in the institutions which make decisions on the legal and illegal use of violence. This situation reflects the hierarchy between the sexes and, in addition, is supported by the widespread belief that women should not participate in activities involving or concerning violence. It may even be said that androcentric (social) norms have an impact on the legal constructions of violent crime, institutional morality, and everyday social practice.

I would like to shed some light on how the misrecognition and nonrecognition of violence against women and of violence perpetrated by women limit their possibilities for participating in society. The victim of violence is feminized, and thus holds a lower social position than the perpetrator. Furthermore, other low-status groups are also at risk of feminization and, as a result, belittlement (Fraser 1996, 4). Since the harms I discuss here are rooted in misrecognition, designing appropriate countermeasures must include behaviour aimed at reshaping the relations involved in the recognition of violence. This means that if we want to limit the use of violence and its strangling effects on women's lives, we need to reshape cultural patterns of behaviour and widespread beliefs concerning violence. 
The concepts of recognition, and hence misrecognition, employed in this paper are drawn from Nancy Fraser's works. As Fraser states, the category of recognition is used by modern social movements and thinkers in order to "unpack the normative base of political claims" (ibid. 1). Recognition is a category that allows subjects' autonomy to be set in an interpersonal frame, and thus grasp the moral stakes present in many contemporary struggles (ibid. 1). The base for claims for social justice in Fraser's approach is participatory parity (ibid. 25), a norm that can be accepted by people with different political views and concepts of good. According to Fraser, if we justify any kind of claims for social justice, including claims for recognition, it is necessary to assume conditions of participatory parity, which, as she points out, include reciprocal recognition (Fraser \& Honneth 2003, 44). Fraser argues that "recognition is a remedy for social injustice, not the satisfaction of a generic human need" (ibid. 45)ํ․

Misrecognition is a concept used to grasp the status of injury emerging from social relations (Fraser 1996, 25), grounded in cultural patterns of representation, interpretation, and communication (ibid. 7). Relations of recognition define certain groups as less prestigious, less esteemed or of lesser value in comparison to other groups in a society (ibid. 8-9). Misrecognition prevents certain individuals or groups from participating in social life on equal and fair terms, and therefore it is morally wrong (ibid. 25). Harms derived from a state of injustice can assume a material form in different forms of physical violence (Fraser \& Honneth 2003, 76).

Recognition is an issue of moral concern. The building of interpersonal relations is based on recognition. It requires certain competences that need to be cultivated. Recognition requires appropriate behaviour towards someone, which also requires an accurate assessment of a situation. Misrecognition entails accepting a morally fallacious judgement on how to treat other people. Therefore, the education of moral competences goes hand in hand with the struggle for just recognition.

Since violence is one of the harms derived from misrecognition, in designing strategies for the prevention of violence, we need to be mindful of how such actions could affect recognition. However, the complexity of the social mechanisms of violence demands a multidimensional approach, and the task of the scholar here is to "understand how the rules, relations, and their

1 Another concern is raised by advocates of post-identity politics. Following Lois NcNay's critical approach, "the preoccupation with gender identity has enmeshed feminism in a parochial politics of recognition whose limited aims constrain its political imagination and prevent it from engaging in broader democratic debates" $(2010,512)$. I believe this is a valid point, but Fraser was able to escape this limitation by building her concept on participatory parity rather than merely on recognition. 
material effects produce privileges for some people that underlie an interest in their maintenance at the same time that they limit options of others, cause relative deprivations in their lives, or render them vulnerable to domination and exploitation" (Young 2005, 25).

It needs to be noted that while violence is a phenomenon spread across different cultures across the globe, it also takes specific forms based on differences between cultures, which means that motivations for the use of violence, as well as the influence it has on victims, may vary from society to society. Moreover, different societies possess differing understandings of what constitutes violence.

This paper mainly addresses the misrecognition of violence in Western societies, meaning that the specifics of the use of violence in other cultures may be different. However, economic differences between regions and variation in levels of political stability may also influence the ways violence is perpetrated and the number of violent acts. There are many intersecting factors that affect the use of violence, for instance, differences between small towns and big cities, or differences in social status may be just as significant as differences between cultures. While people commit violent acts regardless of their social position, education, etc., certain patterns and intersecting impacts can be identified. As long as the devaluation of women and feminine life patterns are present in societies, the use of violence against women and its impact on their lives will follow.

\section{Misrecognition}

The misrecognition of women as perpetrators of violence and as victims of it can take various forms. Underfeminization is a type of misrecognition that has its source in subjecting women to the same standards as men, while simultaneously ignoring the specific social situation of women, whereas overfeminization indicates the creation of separate standards for women based on the assumption that women and men are completely different, and that women are thus incapable of doing the same things as men, justifying a need to apply universal principles to the actions of both men and women (Fraser 1996, 63).

The victim of a violent act becomes overfeminized. This means that they (the victim) commonly appear to be weak, incapable, overly emotional and irrational. Such a social picture inspires pity and a desire to help, so in certain circumstances it may prove beneficial for victims. A historical example of the influence exerted by such a social picture is the situation of women in Victorian England. This historical situation may be instructive for understanding the feminized figure of the victim. In the Victorian period, women's protection against domestic violence improved visibly, and they were likely to receive a favourable outcome in court cases (Wiener 2004, 3). 
This had further positive results, as women started to feel safer, which allowed them to participate more actively in society (ibid. 34-35).

Yet for a number of reasons relevant to modern western societies, it is misleading to think this would be proper form of recognition today. The feminized figure of the victim is highly ambiguous, as a number of undesirable or simply undervalued traits are associated with femininity. Firstly, according to a widely-held social perception, an emotional - and thus irrational - person is not a reliable witness. As a consequence, such a person is not deemed capable of making decisions about her/himself; therefore, a victim's judgment is often questioned. This makes it easy to question or deny anything that a victim has to say and to enforce other interpretations and, as a result, influence decisions. The issue of credibility is important for the victims' pursuit of justice in court; unfortunately, many victims are judged to be insufficiently credible, and as a result, are denied the possibility of bringing their cases to court (Frochmann 1991, 314). Moreover, a feminized victim figure is seen as someone who lacks agency (passively waits for others to act), and therefore needs to be taken care of. This limits the possibilities for action by victims or potential victims, as well as their attempts to seek help.

Women are perceived as people to be rescued from their male abusers, but exclusively by another, this time heroic, man. This narration had very grim consequences for colonial discourse, and seems to have had quite a similar influence on post-colonial discourse. The necessity to protect women can also be used as a justification for starting wars. Recent examples of such a practice were attempts to justify the war in Afghanistan and fuel Islamophobia by invoking a narrative of ensuring women's safety, as displayed in U.S. foreign policy during George W. Bush's presidency (Butler 2003, 41). While initially the justification for war was the need to protect the U.S. and Western countries from terror attacks, ${ }^{2}$ a rhetoric of liberating Afghan women soon arose. Although the situation of Afghan women under Taliban rule was admittedly terrible, both Western feminists analysing the situation of women in Afghanistan and the Bush Administration, which exploited feminist narratives, ignored other factors, such as poverty and a lack of political stability. Intervention in Islamic countries did not advance respect for women's rights in the region and the situation of war only made women more vulnerable (Rich, 2015). Nonetheless, one needs to be aware that this is not a new political practice - the British Empire used a similar narrative to justify its rule over "savage" peoples in colonized countries (Wiener 2004, 4).

The problem of domestic and partner violence is perhaps less political but no less socially significant. The bulk of data collected in western countries, 
such as the U.S., suggests that intimate violence is 'sexually symmetrical.' There are just as many examples of man-on-woman violence as there are woman-on-man. Yet oftentimes the data do not account for the context in which the violence occurred, and thus fail to give a reliable picture of the patterns of intimate violence (DeKeseredy \& Schwartz 1998). The crucial question to ask here is: why does one partner decide to use violence against the other? Some researchers have proposed studying violent acts within the wider context of abuse in a relationship, in order to enhance our understanding of the dynamics of intimate partner violence. Surveys on domestic violence often fail to account for the wider context of the abuse, and thus are unable to obtain sufficient information and ensure accurate recognition (Dobash \& Dobash 2004, 328). The position of women and men in society is asymmetrical, and therefore it is difficult for many men and scholars who take a gender-blind (androcentric) perspective to grasp the situations in which and mechanism by which women suffer violence or decide to use it. Assuming symmetry and reversibility in the situations of men and women leads to a skewed understanding of women's problems, which entails further harms, for example, in the form of legal repercussions. Therefore, it is essential to allow victims of violence speak about their experiences (Young 1997).

There is no denying that domestic and intimate violence seriously affect the lives of many people, yet men have better chances of escaping from violent relationships than women, as they usually have social and economic advantage over women (Dutka 2015, 4). Unfortunately, despite pleas from feminists and organizations like WHO, which try to highlight the significance of this problem and conduct studies to understand it better, domestic and intimate violence still remains poorly recognized and misunderstood by society at large circles. This results in further harms for victims and potential victims, who are not able to spot signs of abuse beforehand, and are often blamed for their own situation (ibid. 4-5).

Men who perpetrate violence against their partners tend to see their actions as justified (Belknap \& Melton 2005, 3), as they believe that they should control the family (Kelly \& Westmarland 2015, 3), since they are breadwinners and their partners are not. This conception stems from the belief that the masculine role of breadwinner is more important than the feminine role of caregiver, which is derived from the misrecognition of women. Moreover, the assumption that violence is an acceptable way to secure one's interests in a conflict also plays a role here. This shows that such people have poor judgement skills and/or lack the ability to resolve conflicts otherwise.

Women who resort to the use of violence or embrace a social role connected with the use of violence automatically become underfeminized. Studies show that defendants who adhere to traditional gender norms can 
expect leniency from the court (Konns-Witt 2002, 299-300, 305). Thus, skewed gender norms can result in unjust punishment or disproportionally harsh penalties for women who display aggressive behaviour or threaten to use violence. However, as Katherine T. Bartlett points out, asking about women's experience ("women question") does not lead to more favourable outcomes for women during trial, but reveals a deep-seated gender bias, which influences the decisions of judges $(1990,846)$. Furthermore, women who suffer from other forms of disparity, for example, class or racial oppression, are more likely to suffer from such treatment (Simpson 2014) 3 . Moreover, in white-dominated societies with a considerable non-white population, non-white women (particularly black women (Goff, Thomas, \& Jackson 2008) are seen as less feminine and more prone to use violence, which is a common belief that also contributes to social mechanisms that lead to rendering the victimization of these groups of women invisible (Madris 1997, 349-350).

Studies conducted in the U.S. show that the majority of female inmates are victims of abuse themselves, and in many cases, their partner's violence played a factor in their crime. Some were forced to participate in crime by their abusers (Law 2014), while others were sentenced for killing or assaulting their abusers (Levin 2011). There is also another group that is being held responsible for their partners' violence against their children. They are being punished for failing to protect their children (Branch 2014). This creates a situation where women face the danger of imprisonment both for protecting themselves and their children from violence and for allowing abusers to continue their practices. The criminalization of abuse victims has further limiting effects in situations where the law bans convicted felons from voting, which means they lose the ability to elect representatives who would be willing to work to change unjust laws that penalize abuse victims in the first place (McDonough 2015).

The misrecognition of women who fall victim to violence results in their suffering further forms of injustice. The lack of a sufficient recognition in both the public and private arenas creates serious obstacles for women in maintaining interpersonal relationships. It also reduces their chances of receiving a favourable outcome when they seek help from institutions within the criminal justice system. Victims of sexual crimes face an especially harsh and difficult task in convincing law enforcement officials that they indeed fell prey to this type of abuse (Frohmann, 1991). This issue is rooted in social mores regarding sexuality which absolve men from wrongdoing. Due to a so-

3 The way in which gender bias and race bias interact creates a new, specific type of oppression (Bartlett 1990, 844). 
called mentality of conquest, men are expected to be forceful; moreover, they are taught that women's resistance is merely a facade meant to encourage them further. An assumption that women want to be forced to have sex results in a negation of any sexual violence inflicted on them. These beliefs are difficult to fight, as they are supported by imagery found in pornography and pornography-inspired mainstream media (Dworkin 1989, 166). Another problem is unclear definitions of sexual violation and consent (Murphy, 1996).

Rape is usually seen as a women's problem, not as a problem of the men who commit violence against women (ibid. 1996). This approach may prevent an appropriate social understanding of the issue and make it difficult to find suitable remedies. This shows that attempts to regulate the actions of victims, instead of those of the potential perpetrators, lead to victim blaming. A belief that preventing violence is the victims' responsibility still prevails in modern societies and leads to respectability politics. A victim is required to prove her innocence, i.e., that she neither provoked the assault in any way (Madris 1997, 351) nor did she have any ulterior motives to report the crime (Frohman 1991, 215). If she fails she is likely to face social ostracism, which may have consequences in the form of additional violence (Peck, 2013). This prevents women from seeking justice and results in their inability to redefine recognition of this type of violence.

Women are not the only group that suffers from the misrecognition of sexual and domestic violence. Men affected by either of these forms of violence also face harms tied to misrecognition of these problems. They are largely expected to be able to protect themselves from the "weaker sex," and if they are unable to do so they are branded failures, and seen as lacking in manly qualities. But men who suffer from sexual assault from women are in an even worse situation. On the one hand, they are likely to experience denial of their experience. On the other hand, the language used to describe female-onmale sexual violence (sexual violence by a female against a male) hardly even exists (Davies 2002, 204). This fact demonstrates the problem lacks recognition. Even workers in rape crisis centres are prone to deny help to male victims (ibid. 204). The problem of sexual assault perpetrated by one man on another man or boy is better understood, but that does not reduce the victim blaming (ibid. 204). Despite this, many men choose to be silent about being sexually assaulted, be it because victimization has a "female flavour", or for other reasons (e. g., fear of homophobia) (ibid. 2002). However even the possibility of a sexual assault perpetrated by a women is often denied. The lack of an appropriate language prevents victims of such abuse from successful informing others about their traumatic experiences (Rosin 2014). Situations in which this type of violence is hardly ever discussed do not allow misconceptions about them to be dissolved.

Male victims of violence are reluctant to report certain types of crimes committed against them (Belknap \& Melton 2005, 4). This is it out of fear of 
being laughed at or their breaching their assigned role, especially if revealing the truth about the crime would put them in danger of becoming feminized. This situation, when only women can be seen as victims of certain violent crimes, is being continually maintained. The roles of victims and perpetrators are dichotomised and connected to gender roles, thus hiding the experiences of many men who at some point have been violated. Men who speak up about their own victimisation at the hands of women have to challenge hegemonic ideas about who can be a victim and who can be a perpetrator. Those men have to expose and admit their own vulnerability and thus challenge the social hierarchy. This revelation of the truth goes against the interests of men as a collective.

I need to stress that people who do not fall under traditional gender binary are in an even worse situation, and are more likely to be affected by a contradicting narrative. Transgender individuals are more likely to suffer from both physical and sexual abuse than gender-conforming men and women (Stoltzer 2009, 171-172). This issue is complicated and requires the development of a separate approach, but it is still worth mentioning that violence based on gender identity is a separate issue from violence based on sexual orientation, and that the problem is largely underrepresented in the statistics, and therefore, social awareness of this issue is very low (ibid. 177).

The moral judgements that follow these patterns of interpretation, and that cause the victim to be blamed, mitigate the guilt of the perpetrator. This is related to using misrecognition in place of just recognition. Justifying violence by means of the identities of the victim and the perpetrator, rather than the relevant circumstances, whether it was done by the perpetrator or a third party, judging the situation is evidence of underdeveloped ability to apply moral reasoning. Passing such judgements and acting on them enables the reproduction of the patterns responsible for misrecognition.

A belief that women cannot be perpetrators of violence, or even if they can, this kind of violence has little influence or power over the victim, or that the victims are to be blamed for their failure to protect themselves, creates a picture of women as posing no danger to men. Men do not have to live in fear of physical violence from women, yet women have to fear men's physical violence and constantly modify their behaviour out of caution. This constitutes a specific inequality between the genders. The fear of a violent crime functions as an instrument for the informal social control of women (Madris 1997, 342), which leads the women obeying the codes to restrict their behaviour. So a woman who is worthy of protection should not fight neither be able to fight, nor to defend herself, and thus should stay home where she is supposed to be safe (ibid. 350). Violating the codes of appropriate behaviour cause the victim to be blamed (ibid. 343). 


\section{Countermeasures}

Strategies for preventing violence against women need to encompass both cultural and redistributing means. Moreover, it is essential to work with individual perpetrators and victims as well as on the level of society - to reform the means of cultural interpretation and economic disparity between the sexes. However, the aim here is not only to stop aggressive behaviour but also to encourage the participatory parity of women. We have to be aware that some strategies to resolve the problem of violence will be more favourable than others. What kind of approach is needed to make the strategy of violence prevention successful? To answer this crucial question, I will refer to Nancy Frasers paper, After Family Wage. A Postindustrial Thought Experiment (1997), where the author proposes principles which new welfare concepts should meet in order to secure a just treatment for welfare recipients. Those principles concern anti-poverty, anti-exploitation, income equality, leisuretime equality, equality of respect, anti-marginalization and anti-androcentrism (ibid. 45-49). The premise behind these normative principles is that the concept of equality cannot be understood as a simple one, and, further, to ensure its possible application we need to account for different areas of human social experience. Since the source of violence against women and women's poverty both largely lay in disparities between the genders, and both problems are interconnected, the normative frame proposed by Fraser can be modified to apply to violence prevention. Like welfare, the prevention of violence needs to be oriented around several principles, but either problem has it's unique specifications, so strategies designed to deal with either of them also need to address different issues, at least in some points.

Likewise, I believe that stopping violence requires a multidimensional approach. Issues of respect and recognition have to be tied with other dimensions of the problem to successfully give fair and equal protection against violence and its terrible effects for all people regardless of gender. The proper recognition of victims, perpetrators and an understanding of violence should be the first principle.

Victims of violence, especially women and members of other marginalized groups, often require additional economic support. To run away from abusive partner, women and their children need the means to support themselves. Another issue is the costs of court trials, which is often something that many victims cannot afford. Economic reasons considerably limit the possibilities to escape abusive relationships. This is something needed to account for in attempts to stop domestic violence. Actions against violence should also take measures against poverty and economic inequality in order to ensure just protection from violence. I propose this be the second principle.

As another principle I would recommend are anti-androcentric measures. Androcentric patterns of interpretation result through imparted or 
enforced stereotypes and legal norms that reinforce the privileged position of men. According to Fraser, employing this principle entails that masculinist patterns be decentred by revaluing traits and practices that are associated with women and thus undervalued, which, in turn, implies changing both men and women (ibid, 48). I would also include in this frame an antimarginalization principle. Social policies that foster women's full participation in all spheres of social life are necessary to reduce women's vulnerability to violence. Anti-marginalization measures entail creating the conditions for women's participation, such as care facilities for children and the elderly, creating a woman-friendly political environment, and workplaces and financial means for victims to acquire professional skills necessary on the job market (Barnardes 2014, 121) 4 .5. I would include a new principle in this frame, which does not come from Fraser's concept I mention earlier. This would be the principle of enhancing a moral development 6 .

Issues of violence are inevitably correlated with issues of morality. Any choice connected to violence is a moral choice indeed. Why do people choose to restore violence? While answering this question, we can say that in many cases people are told that violence is in certain cases good or justified ${ }^{7}$. Since people, even those who have obtained a higher education, lack moral and ethical teaching (Schrader 1999, 49), their ability to make moral choices is poor. Helping people develop skills to think critically about their moral choices and how their actions affect others around them would likely reduce a number of violent acts. The education systems fails to train people to make judgements in difficult situations, ones in which contradictory rules apply, so

4 Marcia Nina Bernardes states, that many of those and other measures are places somewhere between dimensions of recognition and redistribution $(2014,121)$. $5 \quad$ Additionally anti-marginalization principle should address needs of the members of marginalized groups (other than women), who have higher risk of being subjected to violence, thus strategies of violence prevention have to account for ways, in which people are marginalized and address those as well. Different groups need different forms of help. People with disabilities need different aid than religious or ethnic minorities or homeless individuals. All those groups and women within those groups are more vulnerable to violence that contributes to their further marginalization.

6 Adopting such principle confronts us with the question: How to educate moral skills? For the lack of place this issue will not be addressed in this paper, but it is worth mentioning that there is a link between moral metacognitive reflection and level of moral development, which suggests, that encouraging to reflect about their moral thinking rises a possibility to train moral thinking (Schrader 2003). Moreover discursive competences can be trained by employing Konstanz Method of Dilemma Discussion, developed by Georg Lind and promoted on Polish soil by Ewa Nowak (2013).

7 This is an example of conventional morality, as the reasons for taking action instead of autonomously chosen universal principle are rules taught to one as commonly held (compare: Nowak \& Cern 2008, 396). 
many people haven't developed the cognitive skills essential to making choices between two important moral rules (which rule is more important than the other?) and between rights and interests of people involved (whose good and interest should be prioritised?); therefore, such decisions tend to be made in a very chaotic manner (Schrader 1999). Moreover, poor dialog skills, which entails the ability to make consensual decisions, is also lacking (Nowak \& Cern 2008, 381), which results in opting for control as a means for protecting one's interests; this, in turn, can lead to use of violence to exercise control. People who accept the use of violence also fail at making proper moral choices. Victims of violence lack the ability to think critically about their perpetrators' actions, which is why they blame themselves and justify their abusers' behaviour. Victims, of course, are not to blame for this situation, as the experience of victims shows that condoning the abuse they are forced to suffer is something they learned at home (Lewin 2011). This means they accept unjust treatment because they did not have occasion to learn and internalize different models of interaction and likely did not have educational opportunities that would have allowed them to critique those rules. Moreover, people who are not directly affected by violence, but take part in victim blaming and justifying abuse, also display a poor ability to make moral judgements. The moral development of those people that allows them to make such judgements would also benefit the victims of violence.

The example of the Domestic Violence Perpetrator Programmes (Great Britain) indicates that the rising awareness among perpetrator of violence does indeed reduce the number of violent acts (Kelly \& Westmarland 2015, 2). Moreover, involvement in such programmes to a certain extent allows women to regain some of the freedom they lost due to the violent behaviour of their partners. Unfortunately, this newly attained freedom is usually limited to a few areas of life (such as relationships with family members or friends), and remains restricted in others. Most notably, men proceed to use financial means to control their partners (ibid. 2). Positive changes are often brought on by women themselves, which proves it is crucial to educate them as part of the programme. While the programme is successful in making the lives of women, as well as their children, safer, there is still much to be done. Preventing sexual assaults and serious injuries, and making children feel more secure around their fathers, are its most prominent accomplishments. Many but not all participants improve their behaviours, though some only improve in a limited way. Meanwhile, few men admitted their faults and stopped justifying their abusive behaviour (ibid. 2).

The DVPP remains controversial, despite its good results. Sending abusers to attend a course instead of holding them accountable before the law may create a belief that domestic violence is the result of an illness, not a 
crime. In this case, the blame would be lifted from the offenders. Moreover, on this premise, abusers or potential abusers would not fear an encounter with the justice system. Some even argue that the positive role the DVPP played in the lives of wives and children is uncertain, and can perhaps be attributed to other factors (Bindel 2015). The approach realized by DVPP's practices fails to establish a relation in terms of just recognition between the victim and the abuser.

It is noteworthy that participants had to answer questions about gender norms. Everyone expressed the opinion that gender inequality no longer has influence over people's lives, in contrast to the situation in the past. Moreover they had trouble saying what it meant to be a man or a woman. But a thorough inquiry revealed that the sense of entitlement in establishing norms within the family was justified by the notion of being a family provider rooted in a masculine gender role, and subsequent, the treatment of women as nonproviders, childlike, and inferior. It is also worth noting that after their partaking in the programme, men more often took an active role in parenting, especially those who showed the most signs of change (ibid. 3). This suggests that they started to see child care as a valuable activity.

I would like to draw attention to the fact that the perceived inequality of gender roles is rooted in a lack of appreciation for care providing and house work, which results in misrecognition being suffered by care providers, mainly women. If both roles were seen as equally valuable, this line legitimizing domination would drop. Misrecognition of the roles assigned to women influences the patterns of domestic violence.

Such a programme is successful in preventing violence itself, but goes only halfway in establishing just recognition and enhancing moral development. In particular, it fails to achieve proper recognition for the perpetrators of violence in society. Perpetrators become more aware of the consequences of their actions and improve their behaviour; but at the same time, they neglect to acknowledge their guilt. Such a programme does not seem to account for the marginalization of women or economic issues. It does fairly well in terms of dismantling the androcentric perspective, thanks to the stress it places on the care of children, but at the same time, it does not address the problems of male victims and female perpetrators. However, the DVPP does not exist in vacuum, and other programmes may be running at the same time, compensating for its weak points.

Apart from programmes targeting certain types of violence and abuse, some broader changes are needed. Violent acts against women function within a wider structure of subjugation. Perpetrators themselves are also often victims of some type of violence, including mental abuse in the workplace and 
the use of violence against the more belittled members of society as a way to regain control of their lives ${ }^{8}$.

We also cannot omit the fact that the ideology of violence is connected to the modern, western construction of the concept of gender, in the sense that displays of violence are part of the masculine role, and with some circumstantial exceptions, is absent from feminine role (Luci \& Beanneninger 1991, 403). The dualistic ideology is supported by some feminists, who claim that using and supporting violence is a male domain, as Bell Hooks notes. Yet we should not frame men as the sole perpetrators and main supporters of violence; disregarding the role women play skews the picture and reality of women's lives (Hooks 2000,122) and reinforces a dichotomy of an aggressive, violent man and a submissive female victim, which gives men considerable leverage over women and limits the latter (Madris 1997, 353).

\section{Conclusions}

It is essential that a successful strategy against violence encompass actions on both the societal and individual levels. Since people find themselves in a variety of social situations, and on many intersecting axes of domination and subordination, a one-fits-all approach can cause harm by not accounting for certain specifics. The actions undertaken for society in general need to have a more universal character, while particular instances of the use of violence need to be dealt with by means of a more pragmatic approach. Moreover, ways of proceeding with particular cases need to be integrated with general ones. In order to design a successful strategy for the prevention of violence, I propose the following principles: (1) building relations for just recognition before persons become perpetrators and victims, (2) understanding what violence is, (3) enacting measures against poverty and economic inequality, (4) anti-androcentrism strategies, (5) anti-marginalization strategies, (5) and fostering social, moral and interpersonal competencies in individuals.

While none of these principles takes priority over the others, and certainly a successful strategy for violence prevention needs to employ all of them, I would like to draw attention to the last principle - enhancing moral competences with regard to violence prevention. The relation between the use of violence and moral competences should be studied further. The particular skills necessary for recognition would be of interest to me.

Every person deserves equal protection and to be equally free from the fear of violence. This means the binaries between feminized victim and masculine aggressor, which create disparities between men and women, need to be dismantle. Men succumb to an illusion of safety, at least from female

8 This observation, as Bell Hooks notes, stems from Black thinkers, both men and women, and had not been addressed earlier by other authors $(2000,122)$. 
perpetrators, which is complementary to women's fear of victimization at the hands of men. The situation is highly asymmetrical, which has additional consequences, as the asymmetry prevents the privileged group-men-from understanding how women feel and why they act the way they do.

\section{References}

Bartlett, K. T. 1990. "Feminist Legal Method." Harvard Law Review 103 (4): 829-888.

Branch, C. 2014. "How Some States Treat Battered Victims As Criminals." Available

from:

http://www.huffingtonpost.com/2014/11/17/tondalo-hall-

ultraviolet_n_6174076.html.

Belknap, J. \& Melton, H. 2005. Are Heterosexual Men Also Victims of Intimate Partner Abuse?. National Electronic Network on Violence Against Women. Available from: http://www.vawnet.org/Assoc_Files_VAWnet/AR_MaleVictims.pdf.

Bernardes, M. N. 2014. "Domestic Violence and Gender Oppression: An Analysis of Brazilian Law in Light of a Theory of Democratic Justice." In Zirk-Sadowski, M., Wojciechowski, B., \& Cern, K. M. (Eds.), Legal and Communication Strategies Towards the Recognition of Minority Groups. Dorchester: Ashgate: 113-127.

Bindel, J. 2015. "Beating Our Partner Is a Crime, Not an Illness." Available from:

http://www.theguardian.com/commentisfree/2015/jan/12/beatingyour-partner-crime-not-illness-domestic-violence.

Butler, J. 2003. Precarious Life, the Power of Mourning and Violence. London: Verso.

Davies, M. 2002. "Male Sexual Assault Victims: A Selective Review of the Literature and Implications for Support Services." Aggression and Violent Behavior 7 (3): 203-214.

DeKeseredy, W. \& Schwartz, M. 1998. Measuring the Extent of Woman Abuse in Intimate Heterosexual Relationships: A Critique of the Conflict Tactics Scales. Available from: http://www.vawnet.org/applied-researchpapers/print-document.php?doc_id=388.

Dobash, R. P. \& Dobash, R. E. 2004. “Women's Violence to Men in Intimate Relationships Working on a Puzzle." British Journal of Criminology 44: 324-349. 
Dutka, J. 2014. "Przemoc wobec kobiet i kobieca agresja w kontekście ról płciowych i mylnego uznania (misrecognition)." Filozofia Publiczna $i$ Edukacja Demokratyczna, 2(2014).

Dworkin, A. 1989. Pornography: Men Possessing Women. New York: Penguin Books USA Inc.

Fraser, N. 1997. "After Family Wage. A Postindustrial Thought Experiment." In Fraser, N. Justice Interruptus: Critical Reflections on the Postsocialist Condition. New York: Routledge: 41-66.

Fraser, N. 1996. "Social Justice in the Age of Identity Politics: Redistribution, Recognition and Participation." In Peterson, G. B. (Ed.), The Tanner Lectures on Human Values, 19. Salt Lake City: University of Utah Press.

Fraser, N. \& Honneth, A. 2003. Redistribution or Recognition? A PoliticalPhilosophical Exchange. London: Verso.

Frohmann, L. 1991. "Discrediting Victims Allegations of Sexual Assault: Prosecutorial Accounts of Case Rejections." Social Problems 38 (2): 213-216.

Goff, P. A., Thomas, M. A., \& Jackson, M. C. 2008. “Ain't I a Woman?: Towards an Intersectional Approach to Person Perception and Group-based Harms." Sex Roles 59: 392-403.

Hooks, B. 2000. Feminist Theory: From Margin to Center. London: Pluto Press.

Kelly, L. \& Westmarland, N. 2015. Domestic Violence Perpetrator Programmes Steps to Change Executive Summary. Available from: http://respect.uk.net/wp-content/uploads/2015/01/Project-Mirabalexecutive-summary-EMBARGO-00.01-MONDAY-12-JANUARY2015.pdf.

Koons-Witt, B. A. 2002. "The Effect of Gender on the Decision to Incarcerate Before and After the Introduction of Sentencing Guidelines." Criminology 40 (2): 297-327.

Law, V. 2014. "Trapped In The Dark: Marissa Alexander and How Our Twisted Legal System Re-Victimizes Domestic Violence Survivors." Available from:

http://Www.Salon.Com/2014/05/16/Trapped_In_The_Dark_Marissa_ Alexander_And_How_Our_Twisted_Legal_System_Re_Victimizes_Dome stic_Violence_Survivors/.

Levin, V. 2011. "Alternative Sentences Sought for Domestic Violence Victims." Available from: http://www.legislativegazette.com/articles-c-201106-13-78275.113122-alternative-sentences-sought-for-domesticviolence-victims.html.

Luci, P. \& Beanneninger, M.A. 1991. "Aggression by Women: Mores, Myths, and Methods." In Beanneninger, R. (Ed.), Targets of Violence and Aggression. Amsterdam: North Holland.

Madris, E. I. 1997. "Images of Criminals and Victims: A Study on Women's Fear and Social Control." Gender and Society 11 (3): 342-356. 
Mcdonough, K. 2015. "This Is By No Means a Conclusion: Marissa Alexander Is Released, but Her Struggle for Justice Continues." Available from: Http://Www.Salon.Com/2015/01/28/This_Is_By_No_Means_A_Conclu sion_Marissa_Alexander_Is_Released_But_Her_Struggle_For_Justice_Co ntinues/.

McNay, L. 2010. "Feminism and Post-Identity Politics: The Problem of Agency." Constellations 17 (4): 512-525.

Murphy, T.W. 1996. "A Matter of Force, Redefinition of Rape". Available from: http://www.d.umn.edu/cla/faculty/jhamlin/3925/Readings/Force.ht $\mathrm{ml}$.

Nowak, E. \& Cern, K. M. 2008. Ethos w życiu publicznym. Warszawa: PWN.

Nowak, E. 2013. Experimental Ethics. A Multidisciplinary Approach. Münster: LIT.

Nowak, E., Schrader, D., \& Zizek, B. (Eds.) (2013). Educating Competencies for Democracy. Bern - New York - Berlin: Peter Lang Publishing.

Peck, A. 2013. "Victim's House Burned Down After She Accuses Football Star of Rape." Available from: http://thinkprogress.org/health/2013/10/14/2777431/maryvillemissouri-rape/.

Rich, J. 2014. "Saving Muslim Women: Feminism, U.S. Policy and the War on Terror." Available from: https://www.usfca.edu/International_Studies/international_affairs_re view/fall2014/articles/Saving_Muslim_Women/.

Rosin, H. 2014. "When Men Are Raped." Available from: http://www.slate.com/articles/double_x/doublex/2014/04/male_rap e_in_america_a_new_study_reveals_that_men_are_sexually_assaulted.ht $\mathrm{ml}$.

Schrader, D. E. 1999. "Justice and Caring: Process in Collage Students' Moral Reasoning Development." In Katz, M., Noddings, S. N., \& Strike, K. A (Eds.), Justice and Caring: The Search for Common Ground in Education. New York: Teachers College Press.

- - . 2003. "Moral Metacognition in Adolescence and Adulthood." In Demick, J. \& Andreoletti, C. (Eds.), Handbook of Adult Development. New York: Kluwer Academic/Plenum: 301-327.

Simpson, M. 2014. "Standing Our Ground: Reproductive Justice for Marissa Alexander." Available from: realitycheck.org/article/2014/04/18/standing-ground-reproductivejustice-marissa-alexander/.

Stotzer, R. L. 2009. "Violence Against Transgender People: A Review of United States Data." Aggression and Violent Behavior 14: 170-179.

Wiener, M. J. 2004. Men of Blood Violence, Manliness and Criminal Justice in Victorian England. Cambridge: Cambridge University Press. 
Young, I. M. 1997. "Feminism And The Public Sphere Asymmetrical Reciprocity: On Moral Respect, Wonder, and Enlarged Thought." Constellations 3 (3): 340-363.

2005. On Female Body Experience "Throwing Like a Girl" and Other Essays. New York: Oxford University Press.

Joanna Dutka (Poznań)

Misrecognized Violence Against Women and Perpetrated by Women. Seeking Remedies

\begin{abstract}
This paper explores the misrecognition of women's experience with violence in order to understand better what kinds of approaches to the problem would make it possible to design successful strategies for the prevention of violence. Violence itself, as well as common misconceptions regarding its mechanisms, carries ramifications that go far beyond direct and physical injury. The prevalence of violence and lack of social awareness regarding its mechanisms result in limitations to the social participation of many individuals and groups. Among the groups affected, women have an important place, both due to their number and the way that femininity relates to and disturbs other identities.
\end{abstract}

Keywords: Physical violence, domestic abuse, androcentrism, misrecognition, sexual violence, gender norms

Doi: $10.14746 /$ eip.2015.1.13 